AperTO - Archivio Istituzionale Open Access dell'Università di Torino

\title{
How long does victimisation foster fear of crime? A longitudinal study
}

\section{This is the author's manuscript}

Original Citation:

Availability:

This version is available http://hdl.handle.net/2318/79481

since 2015-09-13T07:27:07Z

Published version:

DOI:10.1002/jcop.20408

Terms of use:

Open Access

Anyone can freely access the full text of works made available as "Open Access". Works made available under a Creative Commons license can be used according to the terms and conditions of said license. Use of all other works requires consent of the right holder (author or publisher) if not exempted from copyright protection by the applicable law. 


\section{How long does victimization foster fear of crime? A} longitudinal study

\begin{tabular}{|r|l|}
\hline Journal: & Journal of Community Psychology \\
\hline Manuscript ID: & JCOP-09-121.R2 \\
\hline Wiley - Manuscript type: & Research Article \\
\hline Keywords: & Fear of crime, Victimization, Longitudinal research \\
\hline \multicolumn{2}{r}{} \\
\end{tabular}

\section{S) ScholarONE \\ Manuscript Central}


Running head: VICTIMIZATION AND FEAR OF CRIME

How long does victimization foster fear of crime? A longitudinal study

Silvia Russo and Michele Roccato

University of Torino

\begin{abstract}
Authors note
Silvia Russo, Department of Psychology, University of Torino, Via Verdi 10, 10124 Torino, Italy. Telephone: ++390116702055, Fax: ++390116702061, E-mail: silvia.russo@ unito.it Michele Roccato, Department of Psychology, University of Torino, Via Verdi 10, 10124 Torino, Italy. Telephone: ++390116702015, Fax: ++390116702061, E-mail: michele.roccato@unito.it (corresponding author)
\end{abstract}




\begin{abstract}
We studied the relationship between victimization and fear of crime longitudinally, analyzing data from the Observatory of the North-West (Italian national sample, $N=1,701$, two waves: January 2006 and January 2007). We modeled fear of crime at $T_{2}$ using as independent variables: (a) the main socio-demographic variables and fear of crime, as assessed at $\mathrm{T}_{1}$; (b) direct victimization; and (c) indirect victimization. Recent direct victimization was the most effective victimization predictor of both concrete and abstract fears, followed by multiple or repeat direct victimization. On the other hand, direct victimization occurring in the 12 months before the first wave did not influence fear. Recent indirect victimization and, above all, multiple or repeat indirect victimization influenced concrete, but not abstract, fear of crime, while direct victimization occurring in the 12 months before the first wave did not foster fear. We discuss the limits of this work and possible further directions.
\end{abstract}

Abstract world count $=150$

Keywords: Fear of crime, Victimization, Longitudinal research 
Victimization may be a very negative experience, for many different reasons. It may be physically harmful, especially in the case of violent victimization, such as robbery, assault, or rape (Gidycz \& Koss, 1991). It may be economically harmful, especially if it interferes with employment (temporarily or permanently) (Van Dorn, 2004). Finally, it may have severe psychological consequences. Some of these are psychological distress (Norris \& Kaniasty, 1994), post-traumatic stress disorder (Resnik, 1987), lowered levels of well-being (Denkers \& Winkel, 1998), and lowered perceptions of health (Koss, Woodruff, \& Koss, 1990). The main reason why victimization is so psychologically negative is the perpetrator's intention to cause harm (Craig-Henderson \& Sloan, 2003). The severity of the psychological consequences of victimization mainly depends on the kind of victimization suffered and on personal (mostly physical, psychological, and economic) vulnerability (Norris, Kaniasty, \& Thompson, 1997).

In the psychological and criminological literatures many studies have analyzed the effects of victimization on fear of crime. Early researchers, mainly in the S-R paradigm, expected to find strong, direct links between victimization and fear of crime. Although often implicit, this expectation was consistent with the assumptive perspective (Janoff-Bulman, 1989). According to this model, under "normal" conditions, people tend to develop an image of the relation between themselves and their social world that is based on three unquestioned assumptions: (a) benevolence of the impersonal world and of other people; (b) the existence of a just, meaningful and controllable world; and (c) self-worth. Involvement in negative events, such as disease, accidents, natural disasters, and victimization may jeopardize such assumptions, and thus hamper people's well-being. Criminal victimization, beyond undermining people's quality of life, may also make them more afraid of crime. However, contrary to this expectation, research has shown the most fearful social categories_-women and the elderly — to be the least victimized ones (Balkin, 1979; Hindelgang, 1974). Thus, a "victimization-fear paradox" was detected (LaGrange, Ferraro, \& Supancic, 1992; Skogan, 1993), and a number of analyses have been done to try to understand it. We classify these analyses into three main categories (for a more detailed review, see Hale, 1996). 
1. Some researchers (see for instance Farrall, Bannister, Ditton, \& Gilchrist, 2000) have pointed out that most of the studies that detected the paradox used bivariate analyses, without considering an individual's vulnerability and coping skills. Multivariate analyses, controlling for the vulnerability of the respondents (assessed using their socio-demographic characteristics as proxy variables), showed that a strong relationship between fear and victimization does exist.

2. From slightly different perspectives, Taylor (1983) and Petrosino, Fellow, and Brensilber (1997) showed that, after experiencing victimization, people are pushed to readjust their representation of their relations with themselves and their social reality, mainly by: (a) searching for new meaning in their experiences; (b) attempting to regain mastery not only over the particular event they experienced, but also over their whole life; and (c) trying to increase their lowered self-esteem. Their need for restructuring is so strong that they sometimes even build a positively biased representation of their relationship with the social world; such a representation, in turn, tends to effectively fight victimized people's increased fear of crime. In this view, the insignificant direct relation between victimization and fear of crime may be explained by the effectiveness of coping strategies, which mediate between victimization and fear of crime.

3. According to Gomme (1988) and Skogan and Maxfield (1981), fear of crime is strongly influenced by indirect victimization more so than by direct victimization: that is, victimization of people in one's own social network, both because the latter is much more widespread that the former and because it "allows one's imagination full scope without perhaps the same urgency to find some coping strategy" (Hale, 1996, p. 105).

Thus, as a whole, when analyzing the link between victimization and fear of crime, ability to cope with victimization seems to play a very important role (Collins, Taylor, \& Skogan, 1990; Winkel, 1998; Winkel \& Denkers, 1995). Generally speaking, the literature shows that people try actively to neutralize the negative effects of victimization using coping strategies such as denial of psychological and physical injury, acceptance of responsibility, and appeal to higher motives. The degree of success of these strategies, which—according to the neutralization techniques perspective 
(Agnew, 1985) will depend on the nature of the victimization, the characteristics of the individual, the individual's degree of social support, and the characteristics of the individual's community—moderates the relationship between victimization and fear of crime: Unsuccessful coping will result in problems and difficulties in coping with subsequent victimization and thus will increase people's fear of crime, while successful coping will not (Winkel, 1999).

Despite the strength of these results, three main problems remain open. First, we do not yet know how long victimization continues to foster fear of crime. Norris and Kaniasty (1994) showed that rape tends to foster fear of crime for about nine months, and that after this period its effects tend to diminish. However, rape is fortunately a rare event, and the literature shows that the most relevant effects on fear of crime are those exerted by more frequent and less severe experiences of victimization, such as burglary, pick-pocketing, and bag-snatching (Hale, 1996). Unfortunately, we do not have any information about the enduring effects of these forms of micro-criminal victimization. In Amerio and Roccato's longitudinal research (2007), direct and indirect victimization experiences proved to be the most effective predictors of the trend in fear of crime between October 2002 and January 2004. In their secondary analysis, however, these authors could not control for victimization occurring between their first and their second survey. Thus, they could not disentangle the enduring effects of past victimization from the effects of multiple victimization (being a victim of different crimes) and of repeat victimization (consisting in repeatedly being a victim of the same crime). This was a particularly severe problem, as the literature shows that past victimization is a very efficient predictor of future victimization, both of multiple (Hope, Bryan, Trickett, \& Osborn, 2001) and of repeat victimization (Johnson, Bowers, \& Hirschfield, 1997). As a matter of fact - this is the second open problem in this literature-at present, the data about the effects on fear of crime of repeat victimization and of multiple victimization are still somewhat weak. Emblematically, Winkel, Blaauw, Sheridan, and Baldry (2003), who did one of the more convincing longitudinal studies on this topic, showed that—if individuals' fear of crime at $\mathrm{T}_{1}$ is statistically kept under control—-there are no fear of crime differences among people who have 
been singular victims, who have been repeat victims and who have not been victims at all.

However, their repeat-victims subsample was both very small, as it contained just 25 people, and likely distorted by a severe self-selection bias. Indeed, in order to participate in their research, people had to answer questionnaires analyzing victimization and fear of crime each week for 30 months. Based on the methodological literature (e.g. Behr, Bellgard, \& Rendtel, 2005; Magruder \& Nattrass, 2006), it is plausible that their repeat victims who agreed to answer such a large number of questionnaires about victimization were people who could effectively cope with it. Thus, Winkel and colleagues may have underestimated the effects of repeat victimization on fear of crime.

The last open problem in the literature arises from most studies' focus on concrete fear (sometimes labeled as fear of crime: see Amerio \& Roccato, 2005): that is, a sensation of agitation or anxiety for one's own safety or for that of one's personal property. This is a fear that people experience both in the actual moment of danger and as a reaction to potential danger. However, the literature shows that another kind of fear is also relevant: abstract fear (sometimes labeled as concern for crime as a social problem: see Amerio \& Roccato, 2005), a feeling linked more to a state of agitation about the spread of criminal acts in one's own country than to personal fear of becoming a crime victim. Accordingly, abstract fear concerns the safety and well-being of the community or of the entire society, while concrete fear concerns the safety and well-being of the individual (Furstenberg, 1971). It is far from surprising that concrete fear has been studied much more than abstract fear, given its stronger links with daily life and its negative consequences, from the psychological (Perkins \& Taylor, 1996), the behavioral (Liska, Sanchirico, \& Reed, 1988; Miethe, 1995; Vacha \& McLaughlin, 2004), and the social (Goodstein \& Shotland, 1980; Langworthy \& Whitehead, 1986; Oliver, Huxley, Bridges, \& Mohamad, 1997; Pantazis, 2000; Perkins, Florin, Rich, Wandersman, \& Chavis, 1990; Saegert \& Winkel, 2004; Wilson, 1975) points of view. As a matter of fact, nearly nothing is known about the enduring link between victimization and abstract fear: The one study we are aware of, by Amerio and Roccato (2007), did not show any 


\begin{abstract}
link between victimization and the 2002-2004 trend in abstract fear of crime. However, this study had the limits we mentioned above.
\end{abstract}

\title{
Goals
}

In this longitudinal study, building on the work of Amerio and Roccato (2007), we set out to analyze links between victimization and abstract and concrete fear of crime in an Italian national sample, disentangling the enduring effects exerted by singular victimization from those exerted by multiple or repeat victimization.

\section{Method}

\section{Data set}

We did a secondary analysis on the longitudinal data collected in January $2006\left(\mathrm{~T}_{1}: N=\right.$ $4,981)$ and in January $2007\left(\mathrm{~T}_{2}: N=2,584\right)$ by the Observatory of the North-West (www.nordovest.org), a research institution of the University of Torino. ${ }^{1}$ We merged these two databases, and used in our analyses only the 1,701 people who participated in both two waves. Merging the two files allowed us to take full advantage of the longitudinal nature of the Observatory data. However, panel attrition—besides causing loss of participants—caused a slight loss in data generalizability: As shown in Table 1, people who participated in both waves were slightly different from the Italian general population, as our sample was somewhat older, more educated, and more urban than the Italian population. Moreover, women were over-represented. Based on the methodological literature, such a slight distortion—comparable to that characterizing Amerio and Roccato's (2007) longitudinal research—was expected, as it systematically affects panels surveyed in just a few waves (e.g. Loosveldt \& Carton, 2001, 2002).

We used three families of variables.

1. Two sets of control variables, assessed in January 2006. One set comprised the main socio-demographic variables: gender $(0=$ men, $1=$ women $)$, age, years of formal education, geopolitical area of residence (four dummies: North-Western Italy, North-Eastern Italy, Southern Italy and the Italian Islands; we used residence in Central Italy as the reference category), and size 
of area of residence (dummy variable: 0 for people living in towns with fewer than 100,000 inhabitants, and 1 for people living in larger towns). The other set, as in Robinson, Lawton, Taylor, \& Perkins (2003), comprised the levels of concrete or of abstract fear as assessed in the first survey. The following two items were used to assess fear of crime: (a) "Think of micro-criminality. How would you define the situation regarding this problem in your area of residence?"; and (b) "Think of micro-criminality. How would you define the situation regarding this problem in Italy?". Because the first item refers to criminality in one's own life space, whereas the second refers to criminality throughout Italy, consistently with the Italian literature on fear of crime (Amerio \& Roccato, 2005, 2007; Nardi, 2003; Roccato, 2007), we considered the first item to operationalize concrete fear of crime and the second to operationalize abstract fear of crime.2

2. Direct and indirect victimization. Both in January 2006 and in January 2007, participants reported whether they had been directly victimized, if at least a person in their social network had been victimized, or whether they had not been directly or indirectly victimized at all, taking into account seven offenses: (a) assault, (b) vandalism, (c) burglary in their own home, (d) car theft, (e) pick-pocketing or bag-snatching, (f) robbery, and (g) fraud. We classified our participants into four categories based on their experiences with direct victimization: (a) non-directly victimized people $(n=1,202)$, (b) people directly victimized in the 12 months preceding the first survey only $(n=$ 186), (c) people directly victimized in the 12 months between the first and the second survey only $(n=179)$, and (d) people directly victimized both in the 12 months before the first survey and in the period between the first and the second survey $(n=499)$. We built an analogous typology assessing indirect victimization $\left(n s=400,254,308\right.$, and 739 respectively). ${ }^{3}$

3. Concrete and abstract fear of crime measured at $\mathrm{T}_{2}$, assessed by the same items used at $\mathrm{T}_{1}$.

\section{Data analyses}

After describing the 2006-2007 trends in fear of crime among our participants, we did two hierarchic regressions to predict levels of fear in January 2007, one for concrete and one for abstract fear. In the first regression we entered, as control variables, the main socio-demographic variables 
and the individual level of concrete (or of abstract) fear in January 2006. In the second step, we entered our typology of direct victimization, while in the last step we entered our typology of indirect victimization. In both cases, we used non-victimized people as the reference category.

\section{Results}

\section{Trends of Fear of Crime}

Table 2 shows that, as in previous Italian research on this topic (Amerio \& Roccato, 2005, 2007), both in January 2006 and in January 2007, the absolute majority of our participants were at most a little bit afraid of micro-criminality in their area of residence. However, generally speaking, in the 12 months before our first and second waves, we detected significant changes in participants' concrete fear of crime: $\chi^{2}(3)=14.366, p<.001$. In detail, adjusted standardized residual analysis showed that the quota of the little-afraid participants significantly decreased, while those of the quite-afraid and very-afraid participants significantly rose.

Table 3 shows that, consistently with previous Italian results (Amerio \& Roccato, 2005, 2007) in both the waves of our research more than $90 \%$ of the Italians were at least quite afraid of crime. However, as a whole, the association between wave and abstract fear showed to be significant, $\chi^{2}(3)$ $=68.888, p<.001$. In detail, adjusted standardized residual analysis showed that the quota of quiteafraid participants decreased significantly, while that of very-afraid participants rose significantly.

\section{Prediction of Concrete and Abstract Fear of Crime}

Table 4 shows the results of our first hierarchic regression, aimed at predicting our participants' concrete fear in January 2007. The table has three blocks; each block shows the results of one of the three steps of the analysis. The last column of each block shows the result of a standard r-square symmetrical decomposition (Perrone 1977): This statistic allowed us to compute the quota of the variance of our dependent variable explained by each predictor we used. ${ }^{4}$ Net of all the other ones, in each step, two of our control variables exerted an influence on our dependent variable: They were living in a large town, and, above all, concrete fear at $\mathrm{T}_{1}$. Adding our direct victimization typology in step 2 significantly improved the fit of our model. Direct victimization 
occurred before the first wave of our research did not influence concrete fear at $\mathrm{T}_{2}$. On the contrary, repeat or multiple direct victimization, occurring both before the first wave and between the first and the second waves, and, above all, recent direct victimization positively influenced our dependent variable. The latter was more than three times as efficient as the former in fostering concrete fear of crime. Finally, adding our indirect victimization typology in step 3 significantly improved our model's fit again. Indirect victimization occurring in the 12 months before the first and the second wave did not influence concrete fear of crime. On the contrary, recent victimization and, above all, multiple or repeat victimization occurring before the first wave and between the first and the second waves of the research fostered concrete fear. Contrary to the results for direct victimization, the latter was about three times a more efficient predictor of our dependent variable than the former. The influence of indirect victimization, however, was much weaker than that of direct victimization.

Table 5 shows the results of our second hierarchic regression, aimed at predicting abstract fear of crime. Three control variables significantly influenced our dependent variable: Beyond abstract fear measured at $T_{1}$, which was the most efficient predictor and positively influenced our dependent variable, they were education and living in a large town (negative relations). Adding direct victimization in step 2 significantly improved the fit of our model. The pattern of influences we detected was the same one we showed for concrete fear: Recent victimization was much more efficient in predicting abstract fear at $\mathrm{T}_{2}$ than multiple or repeat victimization occurring both before the first wave and between the first and the second ones. Contrary to the results for concrete fear, adding our indirect victimization typology did not significantly improve the fit of our model.

\section{Discussion}

In this study we analyzed the length of the effects of direct and indirect victimization on concrete and abstract fear of crime. We analyzed data collected for an Italian national sample surveyed twice, in January 2006 and in January 2007. Consistently with Amerio and Roccato (2007), we showed that the variables that in multivariate analyses appeared to be the strongest 
predictors of the level of concrete and of abstract fear tended to influence their trends as well. Specifically, in line with cross-sectional studies focusing on the prediction of fear of crime (e.g. Miceli, Roccato, \& Rosato, 2004), living in urban centers—which are characterized by a wide array of social and physical incivilities (Sartori, 2003) and of crime itself (Nardi, 2003)—exerted a positive influence on the trend for concrete fear of crime. On the contrary, living in large urban centers and being a highly educated person negatively influenced the trend in abstract fear of crime scores. This was not surprising, considering that previous studies recognized social peripherality as one of the main factors explaining abstract fear (Roccato, 2007). Our findings provided the same support with respect to victimization. The literature shows that victimization increases fear of crime (Hale, 1996); we showed that it also positively influences its trend, indirectly suggesting the importance of coping in the moderation of the enduring relationship between victimization and fear.

Our longitudinal results shed some new light on the links between victimization, coping, and fear of crime, if only indirectly. They help with interpreting some at-least-partially conflicting results previously gained from cross-sectional analyses. On the one hand, we showed that the effect of recent direct victimization on fear of crime is strong, for both abstract and concrete fear. This was consistent with the assumptive world perspective (Janoff-Bulman, 1989), according to which victimization, jeopardizing people's assumptions of relative invulnerability to negative events and of living in a substantially benevolent and meaningful world, should foster fear of crime.

On the other hand, we showed that such effects are substantially short, and that multiple or repeat direct victimization exerts a weaker effect on fear of crime than singular recent victimization. This result was consistent with the neutralization technique perspective (Agnew, 1985), which suggests that people tend to cope with the negative effects of victimization, trying to neutralize them. Moreover, our hierarchic regressions showed that the effect of indirect victimization on concrete fear was weaker than that exerted by direct victimization but, interestingly, multiple or repeat indirect victimization showed to be a more efficient predictor of concrete fear of crime than 
recent indirect victimization. Consistently with what Hale (1996) wrote about the prediction of the absolute level of concrete fear, this cumulative effect of indirect victimization suggests that coping with indirect victimization may be a somewhat more difficult task than coping with direct victimization, because it does not strongly force the use of effective coping strategies. At the same time, the effect of indirect victimization on abstract fear did not reach statistical significance. This result was consistent with those showing that abstract fear is strongly related to perception of the wider social context (Amerio \& Roccato, 2007). In this light, we may hypothesize that the psychological consequences of an offense involving people in one's own social network are not so severe to affect the societal-level judgment but are still severe enough to affect the evaluation of one's own life space. Future research explicitly aimed at testing this hypothesis will be obviously germane.

As a whole, our findings about the trends of abstract and concrete fear confirmed them to be different constructs related to somewhat different predictors. We showed concrete fear to be directly dependent on the context in which people live - as evinced by the highest fear of crime levels shown by residents of large cities—and on personal vulnerability—as demonstrated by the positive effect exerted by victimization experiences. Personal vulnerability seems to be mainly but transiently affected by recent victimization. At the same time, recent victims showed high levels of abstract fear as well. This implies that recent direct victimization events (in contrast to indirect victimization) also shape the way in which people perceive, represent and evaluate their social world, confirming the central role they play in people's lives. Finally, we showed the abstract fear trend to be related to the degree of social peripherality, with more educated and urban individuals less concerned about crime as a social problem.

Thus, as a whole, we believe our results indirectly showed that victimization activates relevant coping strategies, which need some time to become effective. How much time? Based on our data, we could not answer this question, which would need an ad hoc study, periodically surveying participants about their victimization experiences and about their level of fear of crime. When 
presenting the work of Winkel et al. (2003), we discussed the problems with this kind of research. It is very difficult to reach a satisfactory trade-off between two conflicting needs: to gather data that are both informative and rich, and not heavily distorted by panel attrition Methodological research shows that the smaller the number of the waves, the lower the distortion due to panel attrition (Watson, 2003), and that weighting distorted data may even increase bias (Vandecasteele \& Debels, 2007). Future longitudinal research, carefully taking into consideration the methods shown to reduce panel attrition (for a comprehensive review, see Ribisl et al., 1996; see also Tourangeau \& Ye, 2009) will be welcome.

Amerio and Roccato (2007) concluded their paper writing that "for the sake of the victims of acts of micro-criminality and of the communities in which they live, it would be worthwhile to provide psychological support helping the victimized persons to cope with the material and emotive consequences resulting from the acts of victimization" (p. 99). Our data showed that, to be effective, such help should be plausibly given in the first months after the victimization, especially to socially less-advantaged people, those who have the highest risks of being victimized, of being fearful (Winkel et al., 2003), and of experiencing enduring negative psychological consequences from victimization (Atkeson, Calhoun, Resick, \& Ellis, 1982). According to the literature, rape victims resort to territorial health services more than non-victimized people (Golding, Stein, Siegel, Burnam, \& Sorenson, 1988). Indeed, primary care physicians are relatively easy to reach both for victimized people and for health institutions (Koss, Woodruff, \& Koss, 1990). An empirical test of the effectiveness of a training program aimed at teaching them the techniques of screening and first intervention would be very interesting.

Our research had some limits, mainly because our results stemmed from secondary analysis. The advantages and drawbacks of this method are well-known (e.g. Kiekolt \& Nathan, 1985). In our case, the use of secondary analysis made it possible to obtain low-cost, high-quality longitudinal data gathered for an Italian national sample. However, the variables we could use to assess concrete and abstract fear were not completely satisfactory, mainly because they consisted of 
single items and not in scales. As a matter of fact, such items have been used many times in Italian research (see Amerio \& Roccato, 2005, 2007; Dallago \& Roccato, 2010; Nardi, 2003; Roccato, 2007), leading to consistent results, and showed strong, significant correlations with concrete and abstract fear of crime scales (Parisi \& Roccato, 2009). Nonetheless, future research using more satisfactory measures of fear of crime will be welcome. The second limit of our results concerned our direct and indirect victimization typologies. As victimization is a rather infrequent experience, in spite of the fairly large sample size that we analyzed, we could not analytically study the effect exerted by each kind of victimization on our dependent variables, nor the effect of the number of direct and indirect victimizations experienced by our participants. Moreover, we could not disentangle the effects of multiple and of repeat victimization on our dependent variables. Finally, we did not have any information on the precise moment at which our participants were victimized. Thus, we could not precisely measure the actual length of the effect exerted by victimization on fear of crime. Future research aimed at overcoming these limits will plausibly complete the picture we have drawn here. However, our research also had three main strong points: (a) it was longitudinal, (b) it was performed on a relatively representative sample of the Italian population, and (c) it analyzed, beyond concrete fear of crime, abstract fear as well. Thus, we believe it may be used as a first reference to analyze the enduring effects exerted by victimization on fear of crime. 


\section{References}

Agnew, R. (1985). A revised strain theory of delinquency. Social Forces, 64, 151-167.

Amerio, P., \& Roccato, M. (2005). A predictive model for psychological reactions to crime in Italy:

An analysis of fear of crime and concern about crime as a social problem. Journal of Community and Applied Social Psychology, 15, 17-28.

Amerio, P., \& Roccato, M. (2007). Psychological reactions to crime in Italy: 2002-2004. Journal of Community Psychology, 35, 91-102.

Atkeson, B. M., Calhoun, K. S., Resick, P. A., \& Ellis, E. M. (1982). Victims of rape: Repeated assessment of depressive symptoms. Journal of Consulting and Clinical Psychology, 50, 96-102.

Balkin, S. (1979). Victimization rates, safety and fear of crime. Social Problems, 26, 343-358.

Barbagli, M. (Ed.) (2003). Rapporto sulla criminalità in Italia [Report on the criminality in Italy]. Bologna: Il Mulino.

Behr, A., Bellgard, E., \& Rendtel, U. (2005). Extent and determinants of panel attrition in the European Community Household panel. European Sociological Review, 21, 489-512.

Collins, R. L., Taylor, S. E., \& Skogan, L. A. (1990). A better world or a shattered vision: Changes in life perspectives following victimization. Social Cognition, 8, 263-285.

Craig-Henderson, K., \& Sloan, L. R. (2003). After the hate: Helping psychologists help victims of racist hate crime. Clinical Psychology: Science and Practice, 10, 481-490.

Dallago, F., \& Roccato, M. (2010). Right-wing authoritarianism, big five, and perceived threat to safety. European Journal of Personality, 24, 106-122

Denkers, A. J. M., \& Winkel, F. W. (1998). Crime victims' well-being and fear in a perspective and longitudinal study. International Review of Victimology, 5, 141-162.

Farral, S., Bannister, J, Ditton, J., \& Gilchrist, E. (2000). Social psychology and the fear of crime: Re-examining a speculative model. British Journal of Criminology, 40, 339-413.

Furstenberg, F. (1971). Public reactions to crime in the streets. American Scholar, 40, 601-610. 
Gidycz, C. A., \& Koss, M. P. (1991). Predictors of long-term sexual assault trauma among a national sample of victimised college women. Violence and Victims, 6, 175-190.

Gilligan, S. G., \& Bower, G. H. (1984). Cognitive consequences of emotional arousal. In C. E. Izard, J. Cagan, \& R. B. Zajonc (Eds.), Emotions, cognitions, and behavior (pp. 547-587). Cambridge, MA: Cambridge University Press.

Golding, J. M., Stein, J. A., Siegel, J. M., Burnam, M. A., \& Sorenson, S. B. (1988). Sexual assault history and use of health and mental health services. American Journal of Community Psychology, 16, 625-644.

Gomme, I. M. (1988). The role of experience in the production of fear of crime: A test of a causal model. Canadian Journal of Criminology, 30, 67-76.

Goodstein, L., \& Shotland, R. L. (1980). The crime causes model: A critical review of the relationships between fear of crime, bystander surveillance, and change in the crime rate. Victimology, 5, 133-151.

Hale, C. (1996). Fear of crime: A review of the literature. International Review of Victimology, 4, $79-150$.

Hindelgang, M. (1974). Public opinion regarding crime, criminal justice, and related topics. Journal of Research in Crime and Delinquency, 11, 101-116.

Hope, T., Bryan, J., Trickett, A., \& Osborn, D. R. (2001). The phenomena of multiple victimization: The relationship between personal and property crime risks. British Journal of Criminology, 41, 595-617.

Janoff-Bulman, R. (1989). Assumptive worlds and the stress of traumatic events: Applications of the schema construct. Social Cognition, 7, 113-136.

Johnson, S. D., Bowers, K., \& Hirschfield, A. (1997). New insights into the spatial and temporal distribution of repeat victimization. British Journal of Criminology, 37, 224-241.

Kiecolt, K. J., \& Nathan, L. E. (1985). Secondary analysis of survey data. Beverly Hills, CA: Sage. 
Koss, M. P., Woodruff, W. J., \& Koss, P. G. (1990). Relation to criminal victimisation to health perceptions among women medical patients. Journal of Consulting and Clinical Psychology, $58,147-152$.

LaGrange, R. L., Ferraro, K. F., \& Supancic, M. (1992). Perceived risk and fear of crime: Role of social and physical incivilities. Journal of Research in Crime and Delinquency, 29, 311-334.

Langworthy, R. M., \& Witehead, J. T. (1986). Liberalism and fear as explanations of punitiveness. Criminology, 24, 575-591.

Liska, A. E., Sanchirico, A., \& Reed M. D. (1988). Fear of crime and constrained behavior specifying and estimating a reciprocal effects model. Social Forces, 66, 827-837.

Loosveldt, G., \& Carton, A. (2001). An empirical test of a limited model for panel refusals. International Journal of Public Opinion Research, 13, 173-185.

Loosveldt, G., \& Carton, A. (2002). Utilitarian individualism and panel nonresponse. International Journal of Public Opinion Research, 14, 428-438.

Magruder, J. \& Nattrass, N. (2006). Exploring attrition bias: The case of the Khayelitsha panel study. South African Journal of Economics, 74, 769-781.

Miceli, R., Roccato, M., \& Rosato, R. (2004). Fear of crime in Italy: Spread and determinants. Environment and Behavior, 36, 776-789.

Miethe, T. D. (1995). Fear and the withdrawal from urban life. Annals of the American Academy of Political and Social Science, 539, 15-27.

Nardi, L. (2003). Il senso di insicurezza [The feeling of insecurity]. In M. Barbagli (Ed.), Rapporto sulla criminalità in Italia [Report on criminality in Italy] (pp. 525-554). Bologna: Il Mulino.

Norris, F. H., \& Kaniasty, K. (1994). Psychological distress following criminal victimization in the general population: Cross-sectional, longitudinal, and prospective analyses. Journal of Consulting and Clinical Psychology, 62, 111-123. 
Norris, F. H., Kaniasty, K., \& Thompson, M. P. (1997). The psychological consequences of crime. In R. C. Davies, A. J. Lurigio, \& W. G. Skogan (Eds.), Victims of crime (pp. 146-166). Thousand Oaks, CA: Sage.

Oliver, J., Huxley, P., Bridgess, K., \& Mohamad, H. (1997). Quality of life and mental health services. London: Routledge.

Pantazis, C. (2000). "Fear of crime", vulnerability and poverty: Evidence from the British Crime Survey. British Journal of Criminology, 40, 414-436.

Parisi, T., \& Roccato, M. (2009). Insicurezza e paura del crimine [Insecurity and fear of crime]. In B. Loera \& T. Parisi (Eds.). Osservatorio del Nord Ovest: Rapporti focalizzati 2008 [Observatory of the North-West: Research reports, 2008] (pp. 13-43). Roma: Carocci.

Perkins, D. D., Florin, P., Rich, R. C., Wandersman, A., \& Chavis, D. M. (1990). Participation and the social and physical environment of residential blocks: Crime and community context. American Journal of Community Psychology, 18, 83-115.

Perkins, D. D., \& Taylor, R. B. (1996). Ecological assessment of community disorder: Their relationship to fear of crime and theoretical implications. American Journal of Community Psychology, 24, 63-107.

Perrone, L. (1977). Metodi quantitativi nella ricerca sociale. Milano: Feltrinelli.

Petrosino, A. J., Fellow, S., \& Brensilber, D. (1997). Convenient victims: A research note. Criminal Justice Policy Review, 8, 405-420.

Resnik, P. (1987). Psychological effects of victimisation: Implications for the criminal justice system. Crime and Delinquency, 33, 468-478.

Ribisl, K. M., Walton, M. A., Mowbray, C. T., Luke, D. A., Davidson, W. S., II, \& Bootsmiller, B. J. (1996). Minimizing participant attrition in panel studies through the use of effective retention and tracking strategies: Review and recommendations. Evaluation and Program Planning, 19, 1-25. 
Robinson, J. B., Lawton, B. A., Taylor, R. B., \& Perkins, D. D. (2003). Multilevel longitudinal impacts of incivilities: Fear of crime, expected safety, and block satisfaction. Journal of Quantitative Criminology, 19, 237-274.

Roccato, M. (2007). Victimisation and fear of crime. In K. T. Froeling (Ed.), Criminology: Research focus (pp. 119-141). New York: Nova Publishers.

Saegert, S., \& Winkel, G. (2004). Crime, social capital, and community participation. American Journal of Community Psychology, 34, 219-233.

Skogan, W. G. (1993). The various meanings of fear. In W. Bilsky, C. Pfeiffer, \& P. Wetzels (Eds.), Fear of crime and criminal victimisation (pp. 131-140). Stuttgart: Enke.

Skogan, W. G., \& Maxfield, M. G. (1981). Coping with crime. Beverly Hills, CA: Sage.

Taylor, S. E. (1983). Adjustment to threatening events: A theory of cognitive adaptation. American Psychologist, 38, 1161-1174.

Tourangeau, R., \& Ye, C. (2009). The framing of the survey request and panel attrition. Public Opinion Quarterly, 73, 338-348.

Vacha, E. F., \& McLaughlin, T. F. (2004). Risky firearms behavior in low-income families of elementary school children: The impact of poverty, fear of crime, and crime victimisation on keeping and storing firearms. Journal of Family Violence, 19, 175-184.

Vandecasteele, L., \& Debels, A. (2007). Attrition in panel data: The effectiveness of weighting. European Sociological Review, 23, 81-97.

Van Dorn, R. A. (2004). Correlates of violent and non-violent victimization in a sample of public high school students. Violence and Victims, 19, 303-320.

Vidoni Guidoni, O. (2004). La criminalità [Criminality]. Roma: Carocci.

Watson, D. (2003). Sample attrition between waves 1 and 5 in the European Community Household panel. European Sociological Review, 19, 361-378.

Wilson, J. Q. (1975). Thinking about crime. New York: Basic Books. 

Winkel, F. W. (1998). Fear of crime and criminal victimization: Testing a theory of psychological incapacitation of the "stressor" based on downward comparison processes. British Journal of Criminology, 38, 473-485.

Winkel, F. W. (1999). Repeat victimization and trauma-susceptibility: Prospective and longitudinal analyses. In J. J. M. Van Dijk, R. G. H. Van Kaam, \& J. Wemmers (Eds.), Caring for crime victims (pp. 207-221). Monsey: Criminal Justice Press.

Winkel, F. W., Blaauw, E., Sheridan, L., \& Baldry, A. C. (2003). Repeat criminal victimization and vulnerability for coping failure: A prospective examination of a potential risk factor. Psychology, Crime and Law, 9, 87-95.

Winkel, F. W., \& Denkers, A. (1995). Crime victims and their social network: A field study on the cognitive effects of victimization, attributional responses, and the victim-blaming model. International Review of Victimology, 4, 309-322. 


\section{Footnotes}

1. Three times a year the Observatory conducts a mail survey on a panel representing the general Italian population according to the main socio-demographic (gender, age, education, geopolitical area of residence, size of area of residence) and political (vote cast at the last National Election) variables, aimed at studying a number of issues of culture, politics, economy, and society. Data and methodological details are available from its Web site (www.nordovest.org). The sample used in the second wave was much smaller than that used in the first one because of an Observatory budget cut in 2007. However, it was representative of the Italian population.

2. It is appropriate to assume that our participants all knew the definition of "micro-criminality", in that its Italian translation ("microcriminalità", which refers to crimes such as pick-pocketing, bag-snatching, theft, vandalism, etc.) is a widely used term (Barbagli, 2003; Vidoni Guidoni, 2004)and commonly recurs in local and national newspapers as well as in local and national newscast. For instance, Il corriere della sera's website (www.corriere.it, the most read Italian daily) shows that, between 1992 and 2010 the word "microcriminalità" appeared 1,232 times in published articles. .

3. Although fairly large, our sample was not large enough to analytically take into account each victimization experience, particularly for direct victimization. Indeed, people who experienced direct multiple or repeat victimization ranged from 0 (for assault) to 69 (for vandalism). The average number of directly victimized people across the seven victimizations analyzed was 15.85 . Participants indirectly victimized ranged from 73 (for assault) and 357 (for burglary in their home), with an average number of indirectly victimized people across the seven victimizations of 174.71 .

4. The formula we used was as follows:

Quota of explained variance $=\left(r_{i} * \beta i\right) / R^{2} * 100$

where $r_{i}$ was the bivariate correlation between the $i_{\text {th }}$ independent variable and the dependent variable and $\beta$ was the standardized multiple regression coefficient of the $i_{\text {th }}$ independent variable on the dependent variable (Perrone, 1977). 
Table 1.

Differences between the Italian Population and Our Merged File

\begin{tabular}{lcc}
\hline Women & $52.2 \%$ & $58.3 \%$ \\
Mean age & 50.0 & 51.9 \\
& & $(S D=16.2)$ \\
Years of formal education & 9.2 & 11.3 \\
& & $(S D=3.9)$ \\
People living in large cities $(\geq 100,000$ inhabitants) & $23.9 \%$ & $27.4 \%$ \\
\hline Note. The age of our participants ranged between 18 and 87 years old.
\end{tabular}

Italian population Our participants 
Table 2.

Trend in Concrete Fear of Crime

\begin{tabular}{lcc}
\hline & January 2006 & January 2007 \\
\hline Not at all afraid & 87 & 99 \\
& $(5.1 \%)$ & $(5.8 \% 9$ \\
Little afraid & $1010^{*}$ & 866 \\
& $(59.4 \%)$ & $(50.9 \%)$ \\
Quite afraid & 471 & $563 *$ \\
& $(27.7 \%)$ & $(33.1 \%)$ \\
Very afraid & 133 & $175^{*}$ \\
& $(7.8 \%)$ & $(10.3 \%)$ \\
& 1,701 & 1,701 \\
\hline$N)$ &
\end{tabular}

Note. Adjusted standardized residuals $>2$. 
Table 3.

Trend in Abstract Fear of Crime in Italy

\begin{tabular}{lcc}
\hline & January 2006 & January 2007 \\
\hline Not at all afraid & 1 & 2 \\
& $(0.1 \%)$ & $(0.1 \%)$ \\
Little afraid & 44 & 62 \\
& $(2.6 \%)$ & $(3.6 \%)$ \\
Quite afraid & $1093 *$ & 777 \\
& $(64.3 \%)$ & $(45.7 \%)$ \\
Very afraid & 563 & $860 *$ \\
& $(33.1 \%)$ & $(50.6 \%)$ \\
& 1,701 & 1,701 \\
\hline$N)$ &
\end{tabular}

Note. Adjusted standardized residuals $>2$. 
Table 4.

Prediction of Concrete Fear of Crime in January 2007

\begin{tabular}{|c|c|c|c|c|c|c|c|c|c|c|c|c|}
\hline & \multicolumn{4}{|c|}{ Step 1 (control variables) } & \multicolumn{4}{|c|}{ Step 2 (Step $1+$ direct victimization) } & \multicolumn{4}{|c|}{ Step 3 (Step $2+$ indirect victimization) } \\
\hline & $B$ & E.S. & Beta & $\begin{array}{l}\text { Explained } \\
\text { variance }\end{array}$ & $B$ & E.S. & Beta & $\begin{array}{l}\text { Explained } \\
\text { variance }\end{array}$ & $B$ & E.S. & Beta & $\begin{array}{l}\text { Explained } \\
\text { variance }\end{array}$ \\
\hline Woman & -.000 & .032 & .000 & $.00 \%$ & .004 & .032 & .003 & $.00 \%$ & .004 & .032 & .002 & $.00 \%$ \\
\hline Years of formal education & .003 & .004 & .017 & $.46 \%$ & .002 & .004 & .013 & $.33 \%$ & .001 & .004 & .004 & $.10 \%$ \\
\hline$<30$ years old & .020 & .050 & .009 & $.05 \%$ & .024 & .050 & .010 & $.05 \%$ & .021 & .049 & .009 & $.05 \%$ \\
\hline$>60$ years old & -.012 & .035 & -.008 & $.01 \%$ & -.015 & .035 & -.010 & $.01 \%$ & -.007 & .035 & -.004 & $.01 \%$ \\
\hline $\begin{array}{l}\text { Residence in North- } \\
\text { Western Italy }\end{array}$ & -.014 & .048 & -.009 & $.03 \%$ & -.019 & .047 & -.012 & $.04 \%$ & -.022 & .047 & -.014 & $.04 \%$ \\
\hline $\begin{array}{l}\text { Residence in North-Eastern } \\
\text { Italy }\end{array}$ & -.100 & .054 & -.053 & $1.36 \%$ & -.100 & .054 & -.053 & $1.30 \%$ & -.093 & .054 & -.049 & $1.18 \%$ \\
\hline Residence in Southern Italy & .065 & .056 & .032 & $.68 \%$ & .056 & .056 & .028 & $.57 \%$ & .059 & .056 & .029 & $.58 \%$ \\
\hline Residence in the Italian & -.005 & .074 & -.002 & $.01 \%$ & -.015 & .074 & -.005 & $.02 \%$ & -.003 & .073 & -.001 & $.00 \%$ \\
\hline
\end{tabular}


Victimization and fear of crime

\begin{tabular}{|c|c|c|c|c|c|c|c|c|c|c|c|c|}
\hline islands & & & & & & & & & & & & \\
\hline $\begin{array}{l}\text { Size of area of residence (> } \\
100.000 \text { inhabitants) }\end{array}$ & $.416 * * *$ & .037 & .246 & $30.89 \%$ & $.402 * * *$ & .037 & .238 & $28.49 \%$ & $.403 * * *$ & .037 & .238 & $28.08 \%$ \\
\hline $\begin{array}{l}\text { Concrete fear in January } \\
2006\end{array}$ & $.423 * * *$ & .023 & .393 & $66.51 \%$ & $.414 * * *$ & .023 & .385 & $62.12 \%$ & $.404 * * *$ & .023 & .376 & $59.80 \%$ \\
\hline $\begin{array}{l}\text { Direct victimization in the } \\
12 \text { months before } T_{1}\end{array}$ & & & & & .000 & .051 & .000 & $.00 \%$ & -.010 & .051 & -.004 & $.03 \%$ \\
\hline $\begin{array}{l}\text { Direct victimization } \\
\text { between } \mathrm{T}_{1} \text { and } \mathrm{T}_{2}\end{array}$ & & & & & $.278 * * *$ & .052 & .113 & $5.54 \%$ & $.277 * * *$ & .052 & .113 & $5.46 \%$ \\
\hline $\begin{array}{l}\text { Direct victimization both in } \\
\text { the } 12 \text { months before } \mathrm{T}_{1} \\
\text { and in the } 12 \text { months } \\
\text { between } \mathrm{T}_{1} \text { and } \mathrm{T}_{2}\end{array}$ & & & & & $.116^{*}$ & .060 & .041 & $1.61 \%$ & $.118^{*}$ & .060 & .042 & $2.32 \%$ \\
\hline $\begin{array}{l}\text { Indirect victimization in the } \\
12 \text { months before } T_{1}\end{array}$ & & & & & & & & & .028 & .052 & .013 & $.38 \%$ \\
\hline $\begin{array}{l}\text { Indirect victimization } \\
\text { between } \mathrm{T}_{1} \text { and } \mathrm{T}_{2}\end{array}$ & & & & & & & & & $.113^{*}$ & .049 & .057 & $.49 \%$ \\
\hline
\end{tabular}




\section{Page 27 of 30}

Journal of Community Psychology

Victimization and fear of crime

27

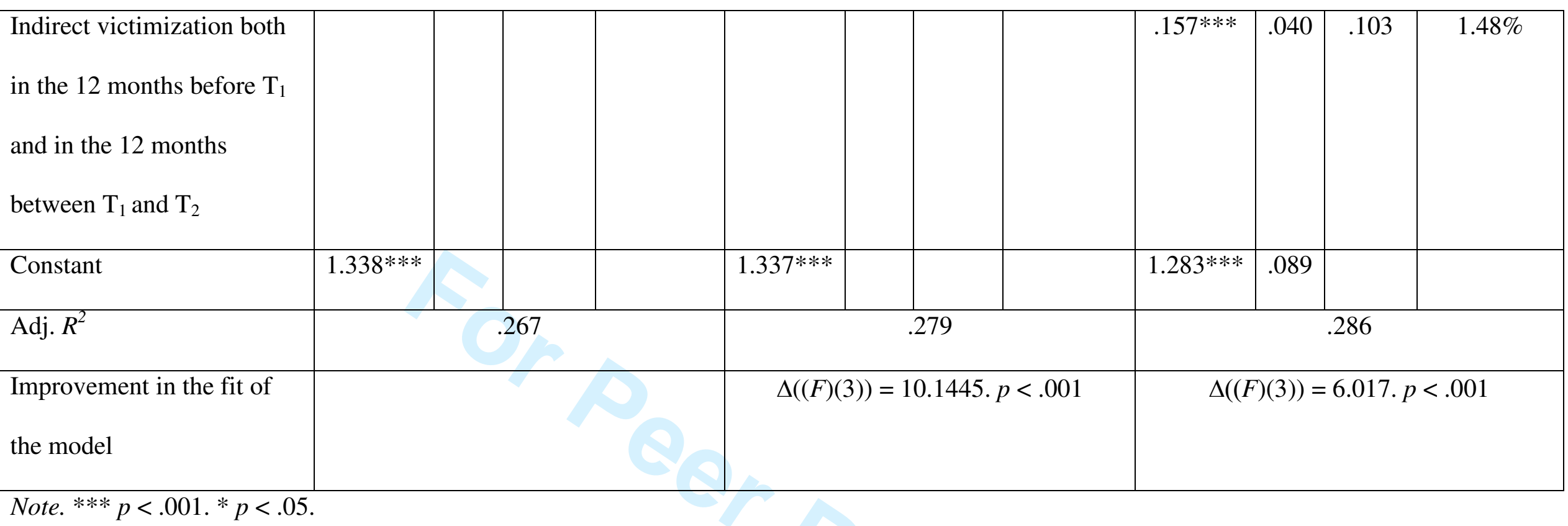


Table 5.

Prediction of Abstract Fear of Crime in January 2007

\begin{tabular}{|c|c|c|c|c|c|c|c|c|c|c|c|c|}
\hline & \multicolumn{4}{|c|}{ Step 1 (control variables) } & \multicolumn{4}{|c|}{ Step 2 (Step $1+$ direct victimization) } & \multicolumn{4}{|c|}{ Step 3 (Step $2+$ indirect } \\
\hline & $B$ & E.S. & Beta & $\begin{array}{l}\text { Explained } \\
\text { variance }\end{array}$ & $B$ & E.S. & Beta & $\begin{array}{l}\text { Explained } \\
\text { variance }\end{array}$ & $B$ & E.S. & Beta & $\begin{array}{l}\text { Explained } \\
\text { variance }\end{array}$ \\
\hline Woman & .045 & .027 & .039 & $.00 \%$ & .048 & .027 & .041 & $.10 \%$ & .048 & .027 & .041 & $1.59 \%$ \\
\hline $\begin{array}{l}\text { Years of formal } \\
\text { education }\end{array}$ & $-.011 * *$ & .004 & -.076 & $1.28 \%$ & $-.012 * * *$ & .004 & -.080 & $.94 \%$ & $-.012 * * *$ & .004 & -.084 & $7.22 \%$ \\
\hline$<30$ years old & -.014 & .042 & -.008 & $.06 \%$ & -.010 & .042 & -.006 & $.06 \%$ & -.011 & .042 & -.007 & $0.05 \%$ \\
\hline$>60$ years old & -.005 & .029 & -.002 & $.02 \%$ & -.002 & .029 & -.002 & $.03 \%$ & .001 & .029 & .001 & $0.00 \%$ \\
\hline $\begin{array}{l}\text { Residence in North- } \\
\text { Western Italy }\end{array}$ & -.066 & .040 & -.056 & $.31 \%$ & -.069 & .040 & -.060 & $.39 \%$ & -.069 & .040 & -.059 & $2.29 \%$ \\
\hline $\begin{array}{l}\text { Residence in North- } \\
\text { Eastern Italy }\end{array}$ & -.037 & .046 & -.026 & $.23 \%$ & -.035 & .042 & -.025 & $.22 \%$ & -.031 & .046 & -.022 & $0.11 \%$ \\
\hline
\end{tabular}




\begin{tabular}{|c|c|c|c|c|c|c|c|c|c|c|c|c|}
\hline $\begin{array}{l}\text { Residence in Southern } \\
\text { Italy }\end{array}$ & .032 & .048 & .020 & $.86 \%$ & .025 & .047 & .016 & $.72 \%$ & .026 & .047 & .017 & $0.52 \%$ \\
\hline $\begin{array}{l}\text { Residence in the Italian } \\
\text { islands }\end{array}$ & -.036 & .063 & -.016 & $.01 \%$ & -.040 & .062 & -.017 & $.02 \%$ & -.033 & .062 & -.014 & $0.07 \%$ \\
\hline $\begin{array}{l}\text { Size of area of residence } \\
\text { (> } 100.000 \text { inhabitants) }\end{array}$ & $-.052 *$ & .030 & -.040 & $12.12 \%$ & $-.066^{*}$ & .030 & -.051 & $11.25 \%$ & $-.067 *$ & .030 & -.052 & $2.92 \%$ \\
\hline $\begin{array}{l}\text { Abstract fear in January } \\
2006\end{array}$ & $.319 * * *$ & .029 & .287 & $85.12 \%$ & $.314 * * *$ & .026 & .283 & $80.02 \%$ & $.312 * * *$ & .026 & .281 & $69.46 \%$ \\
\hline $\begin{array}{l}\text { Direct victimization in } \\
\text { the } 12 \text { months before } T_{1}\end{array}$ & & & & & .040 & .043 & .022 & $.00 \%$ & .037 & .043 & .020 & $2.81 \%$ \\
\hline $\begin{array}{l}\text { Direct victimization } \\
\text { between } T_{1} \text { and } T_{2}\end{array}$ & & & & & & $.148 * * *$ & .044 & $5.34 \%$ & $.149 * * *$ & .044 & .080 & $4.50 \%$ \\
\hline $\begin{array}{l}\text { Direct victimization both } \\
\text { in the } 12 \text { months before } \\
\mathrm{T}_{1} \text { and in the } 12 \text { months } \\
\text { between } \mathrm{T}_{1} \text { and } \mathrm{T}_{2}\end{array}$ & & & & & & $.104 *$ & .051 & $.91 \%$ & $.106^{*}$ & .051 & .050 & $1.32 \%$ \\
\hline Indirect victimization in & & & & & & & & & -.013 & .044 & -.296 & $5.38 \%$ \\
\hline
\end{tabular}


Victimization and fear of crime

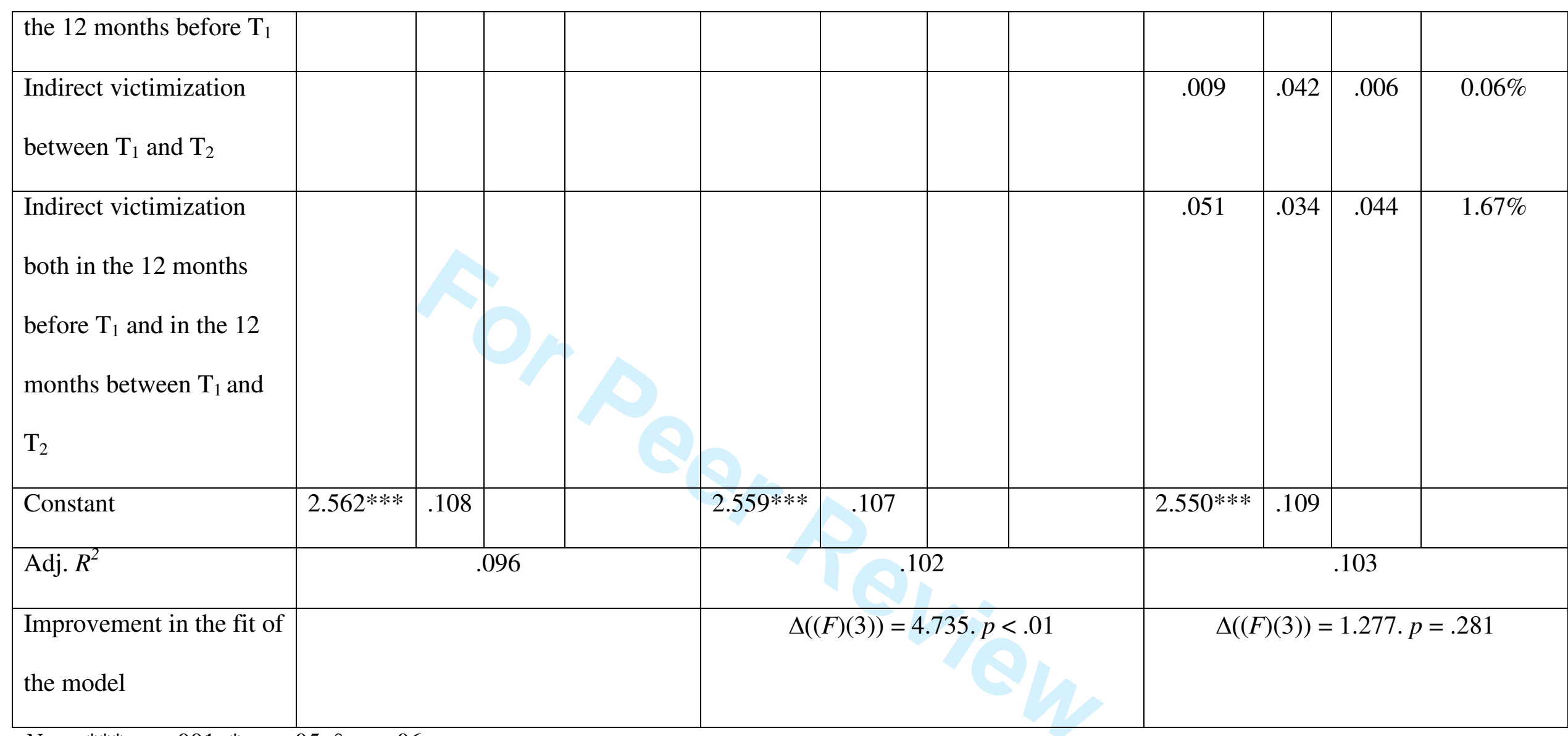

Note. ${ }^{* * *} p<.001 . * p<.05 .^{\circ} p<.06$ 